\title{
The Evolution of Blood Product Use in Trauma Resuscitation: Change Has Come
}

\author{
Mark H. Yazer ${ }^{a, b, c}$ \\ ${ }^{a}$ Department of Pathology, University of Pittsburgh, Pittsburgh, PA, USA; ${ }^{b}$ Department of Pathology, Tel Aviv \\ University, Tel Aviv, Israel; 'Department of Clinical Immunology, University of Southern Denmark, Odense, Denmark
}

\section{Keywords}

Trauma $\cdot$ Resuscitation - Whole blood · Transfusion · Plasma

The only constant in life is change Heraclitus

\section{Dear Editor,}

That quotation is so true, is it not? Think back to when a physician was on call in the 1980s, they had to be at home near a landline at all times, or maybe they were stuck in the hospital because there was not a reliable way to get in touch with them. Then, suddenly, one could buy a portable phone that was as big and heavy as a briefcase, but, if one could afford to purchase and use it, freedom from being tied to a landline while on call could be had! Now our phones fit in our pockets and when we're on call we can be out watching football instead of having to be in sight of a telephone. When there is a demand for improvement, change for the better inevitably happens.

The same is true in trauma resuscitation. Take, for example, the old practice of having bleeding, unstable patients wait until they arrive at the hospital before they receive their transfusions. At that time the ideal fluid for resuscitating these patients was thought to be saline. It is inexpensive, does not transmit diseases, and if it breaks in an ambulance or helicopter then it's only salt water that needs to dry and not a biohazardous material. Liters of saline were administered to trauma patients in an attempt to maintain their blood pressure at near-normal levels. That treatment strategy was all very intuitive, until the practice was actually studied. We then learned about the harm that overzealous crystalloid resuscitation [1-6], as well as aiming for near-normal blood pressures [7], can do to trauma patients and we demanded an improved approach to their early management.

One way we tried to meet this demand was to provide injured patients with blood products as soon as they arrived at the hospital knowing that delaying blood product transfusions costs lives [8]. We developed massive transfusion protocols, stored blood products in refrigerators that were outside of the hospital's main blood bank and so closer to the patients, started using hemostatic adjuncts [9], and encouraged their use early in the resuscitation. Those were positive developments, but there was more that we could do.
But why wait until the patient arrives at the hospital to start the resuscitation? The evolution of blood product use in trauma resuscitation is to bring the blood bank to the patient and get the transfusions started as soon as medical help arrives on the scene. Now we have excellent evidence to prove that early transfusion saves lives. For example, a study of 502 military combat casualties demonstrated that the provision of primarily red blood cells (RBCs) within approximately $30 \mathrm{~min}$ of injury improved both 24 -h and 30 -day survival compared to patients who did not receive any blood products or who received them later in the resuscitation [10]. In the multicenter Prehospital Air Medical Plasma (PAMPER) trial [11], civilian trauma patients, whose median helicopter transport time to the hospital was approximately $40 \mathrm{~min}$, were randomized to receive two units of plasma in addition to the standard of care treatment while en route to the hospital. This study found that 30-day mortality was improved compared to patients who received the pre-hospital standard of care, which in many cases was only crystalloid fluid. In a secondary analysis of this trial, the greatest survival benefit was demonstrated amongst those who received RBCs and plasma compared to those who received plasma alone [12]. In fact, receipt of any blood product during pre-hospital resuscitation yielded a significantly improved 30 -day survival rate compared to those who received crystalloids alone. Interestingly, other secondary analyses of the PAMPER trial demonstrated that the greatest mortality reduction following the administration of prehospital plasma transfusions occurred in patients who suffered from blunt injuries [13], who required $>20 \mathrm{~min}$ to arrive at the hospital [14], and who had traumatic brain injury [15]. Other military and civilian studies have also underscored the importance of the prompt resuscitation of injured patients with blood products $[8,16-19]$.

What about the blood products themselves? How can we improve them to improve patient outcomes? For this answer, we have to look back in history. Whole blood (WB), literally the fluid that donors donate before it is separated into its components for individual storage and transfusion, was the mainstay blood product used for battlefield resuscitation during all of the major wars in the early- and mid-20th century [20-27]. Much of that experience was accumulated using warm, freshly collected WB, which was a matter of necessity in battle. Still, the principle remains that the provi-
(C) 2021 The Author(s)

Published by S. Karger AG, Basel

This is an Open Access article licensed under the Creative Common Attribution-NonCommercial-4.0 International License (CC BY-NC) (http://www.karger.com/Services/OpenAccessLicense), applicable to the online version of the article only. Usage and distribution for commercial purposes requires written permission. 
sion of early and balanced blood product resuscitation when treating hemorrhagic shock is important to improve the patient's outcome; today we have codified this principle into a strategy known as damage control resuscitation [28-32]. So, while individual blood components have their value for correcting single deficiencies, like RBCs for anemia, why take blood apart and put it back together again for the balanced resuscitation of trauma patients when in WB all of the components are present in a naturally balanced ratio?

In fact, we have now come full circle vis-à-vis blood use in trauma. Not all improvements require developing something new, but recognizing that we have gone astray and returning to what worked is itself an improvement. Today, the use of low titer group O WB (LTOWB) is being increasingly adopted at American trauma centers [33-36], and by civilian and military providers in other countries $[37,38]$. The advantages of using LTOWB over individual components have been extensively reviewed elsewhere [39-41] and include the absence of the RBC preservative in LTOWB, the provision of cold stored platelets that might be hyperfunctional compared to conventional room temperature platelets, simplification of the logistics of the resuscitation by providing balanced resuscitation in one bag instead of three, fewer donor exposures and more. In addition, studies are beginning to show that, at the very least [42], injured adult and pediatric LTOWB recipients do not have worse outcomes compared to recipients of conventional components $[43,44]$, and in some cases actually have improved outcomes such as reductions in the quantity of transfused blood products [43, 45-50], or reduced mortality [47, 48, 51-53].

The transfusion of LTOWB requires us to change the way we think about some historical practices. Due to the nature of LTOWB, it is collected only from group $\mathrm{O}$ donors and frequently these donors are males, so as to mitigate the risk of transfusion-related acute lung injury. Furthermore, these donors must also have lowtiter anti-A and anti-B so as to reduce the risk of hemolysis if the unit is transfused to a non-group O recipient [54]. These specifications reduce the available pool of donors, such that at one large American blood collector only $3 \%$ of all donors would be eligible to donate $\mathrm{RhD}$-negative LTOWB!

The solution is to use RhD-positive LTOWB, but this goes against the strongly held belief of never transfusing $\mathrm{RhD}$-positive RBCs or LTOWB to a female of childbearing potential (FCP) whose RhD-type is unknown for fear of alloimmunizing her to the D-antigen and causing hemolytic disease of the fetus and newborn (HDFN). We know that providing blood products early in the resuscitation is very important, but $\mathrm{RhD}$-negative products are not likely to be available in the prehospital or early in-hospital phases of the resuscitation. Does our life-saving improvement come to an abrupt end because of this supply issue? Luckily, there is evidence to support the innovative practice of using RhD-positive RBCs and LTOWB. Several recent studies have modeled the risk of HDFN following the transfusion of $\mathrm{RhD}$-positive blood products to $\mathrm{RhD}$ negative FCPs and found that the risk runs from $0.3 \%$ to approximately $6.5 \%$ depending on the severity of HDFN and the age of the FCP at the time she is transfused, the actual D-alloimmunization rate in trauma patients [55], and other sociological factors [56-58]. In fact, at one large American trauma center, it was estimated that it would take approximately 250 years for between 3 and $30 \mathrm{RhD}$ negative FCPs to develop anti-D [59]; during that time, the authors estimated that nearly 500 injured FCPs would die of hemorrhage if $\mathrm{RhD}$-positive LTOWB was not available for their resuscitation. As these authors indicated, the risk-benefit ratio clearly favors administering blood products early in the resuscitation as HDFN is now a very manageable disease [60].

Another important change to a strongly held belief that is needed when implementing the "new" innovation of LTOWB is that $\mathrm{ABO}$-incompatible plasma will be transfused if the recipient is not group $\mathrm{O}$. This seems very counterintuitive as $\mathrm{ABO}$-compatibility is drilled into us starting in medical school! Using donors with low titers of anti-A and anti-B certainly helps reduce the risk of hemolysis [61-64], but some have speculated that administering ABOincompatible or non-identical plasma can make things worse for recipients [65-70]. However, in two large (albeit retrospective) studies of trauma patients, no differences in mortality were observed between those who received $\mathrm{ABO}$-identical or compatible plasma versus those who received $\mathrm{ABO}$-incompatible plasma [71, 72]. These findings, and the low rate of future HDFN if D-mismatched products are transfused to an RhD-negative FCP, bodes well for the continued use of blood products in the prehospital phase of the resuscitation, a major practice change that has led to significant improvements in the care of injured patients.

\section{Conflict of Interest Statement}

Dr. Yazer lists the following disclosures: Grifols (paid lectures), Terumo BCT (paid lectures, reimbursed travel), Wiley Blackwell (royalties), Octpharma and Verax Biomedical (scientific advisory board honoraria).

\section{Funding Sources}

No funding was obtained to write this editorial.

\section{Author Contributions}

Dr. Yazer conceived and wrote the manuscript.

\section{References}

1 Edwards MJ, Lustik MB, Clark ME, Creamer KM, Tuggle D. The effects of balanced blood component resuscitation and crystalloid administration in pediatric trauma patients requiring transfusion in Afghanistan and Iraq 2002 to 2012. J Trauma Acute Care Surg. 2015;78:330-5.

2 Young JB, Utter GH, Schermer CR, Galante JM, Phan HH, Yang Y, et al. Saline versus Plasma-Lyte A in initial resuscitation of trauma patients: a randomized trial. Ann Surg. 2014;259:255-62.
3 Ley EJ, Clond MA, Srour MK, Barnajian M, Mirocha J, Margulies DR, et al. Emergency department crystalloid resuscitation of $1.5 \mathrm{~L}$ or more is associated with increased mortality in elderly and nonelderly trauma patients. J Trauma. 2011;70:398-400.

4 Harada MY, Ko A, Barmparas G, Smith EJ, Patel BK, Dhillon NK, et al. 10-year trend in crystalloid resuscitation: reduced volume and lower mortality. Int J Surg. 2017;38:78-82.
5 Neal MD, Hoffman MK, Cuschieri J, Minei JP, Maier RV, Harbrecht BG, et al. Crystalloid to packed red blood cell transfusion ratio in the massively transfused patient: when a little goes a long way. J Trauma Acute Care Surg. 2012;72:892-8.

6 Bickell WH, Wall MJ Jr, Pepe PE, Martin RR, Ginger VF, Allen MK, et al. Immediate versus delayed fluid resuscitation for hypotensive patients with penetrating torso injuries. $\mathrm{N}$ Engl J Med. 1994;331:1105-9. 
7 Woolley T, Thompson P, Kirkman E, Reed R, Ausset S, Beckett A, et al. Trauma hemostasis and oxygenation research network position paper on the role of hypotensive resuscitation as part of remote damage control resuscitation. J Trauma Acute Care Surg. 2018;84:S3S13.

8 Meyer DE, Vincent LE, Fox EE, O'Keeffe T, Inaba K, Bulger E, et al. Every minute counts: time to delivery of initial massive transfusion cooler and its impact on mortality. J Trauma Acute Care Surg. 2017;83:19-24.

9 Collaborators ; Shakur H, Roberts I, Bautista $\mathrm{R}$, Caballero J, Coats $\mathrm{T}$, et al. Effects of tranexamic acid on death, vascular occlusive events, and blood transfusion in trauma patients with significant haemorrhage (CRASH-2): a randomised, placebo-controlled trial. Lancet. 2010;376:23-32.

10 Shackelford SA, Del Junco DJ, Powell-Dunford N, Mazuchowski EL, Howard JT, Kotwal RS, et al. Association of prehospital blood product transfusion during medical evacuation of combat casualties in Afghanistan with acute and 30-day survival. JAMA. 2017; 318(16):1581-91.

11 Sperry JL, Guyette FX, Brown JB, Yazer MH, Triulzi DJ, Early-Young BJ, et al. Prehospital plasma during air medical transport in trauma patients at risk for hemorrhagic shock. $\mathrm{N}$ Engl J Med. 2018;379:315-26.

12 Guyette FX, Sperry JL, Peitzman AB, Billiar TR, Daley BJ, Miller RS, et al. Prehospital blood product and crystalloid resuscitation in the severely injured patient: a secondary analysis of the prehospital air medical plasma trial. Ann Surg. 2021;273(2):358-64.

13 Reitz KM, Moore HB, Guyette FX, Sauaia A Pusateri AE, Moore EE, et al. Prehospital plas$\mathrm{ma}$ in injured patients is associated with survival principally in blunt injury: results from two randomized prehospital plasma trials. J Trauma Acute Care Surg. 2020;88:33-41.

14 Pusateri AE, Moore EE, Moore HB, Le TD, Guyette FX, Chapman MP, et al. Association of prehospital plasma transfusion with survival in trauma patients with hemorrhagic shock when transport times are longer than 20 minutes: a post hoc analysis of the pamper and combat clinical trials. JAMA Surg. 2020; 155(2):e195085.

15 Gruen DS, Guyette FX, Brown JB, Okonkwo DO, Puccio AM, Campwala IK, et al. Association of prehospital plasma with survival in patients with traumatic brain injury: a secondary analysis of the pamper cluster randomized clinical trial. JAMA Netw Open. 2020;3: e2016869.

16 Howard JT, Kotwal RS, Stern CA, Janak JC, Mazuchowski EL, Butler FK, et al. Use of combat casualty care data to assess the us military trauma system during the Afghanistan and Iraq conflicts, 2001-2017. JAMA Surg. 2019;154:600-8.

17 Rehn M, Weaver A, Brohi K, Eshelby S, Green L, Røislien J, et al. Effect of prehospital red blood cell transfusion on mortality and time of death in civilian trauma patients. Shock. 2019;51:284-8
18 Brown JB, Sperry JL, Fombona A, Billiar TR, Peitzman AB, Guyette FX. Pre-trauma center red blood cell transfusion is associated with improved early outcomes in air medical trauma patients. J Am Coll Surg. 2015;220:797808.

19 Braverman MA, Smith A, Pokorny D, Axtman B, Shahan CP, Barry L, et al. Prehospital whole blood reduces early mortality in patients with hemorrhagic shock. Transfusion. 2021;61(Suppl 1):S15-21.

20 Auten JD, Lunceford NL, Horton JL, Galarneau MR, Galindo RM, Shepps CD, et al. The safety of early fresh, whole blood transfusion among severely battle injured at us marine corps forward surgical care facilities in Afghanistan. J Trauma Acute Care Surg. 2015; 79:790-6.

21 Chandler MH, Roberts M, Sawyer M, Myers G. The US military experience with fresh whole blood during the conflicts in Iraq and Afghanistan. Semin Cardiothorac Vasc Anesth. 2012;16:153-9.

22 Spinella PC, Perkins JG, Grathwohl KW, Repine T, Beekley AC, Sebesta J, et al. Risks associated with fresh whole blood and red blood cell transfusions in a combat support hospital. Crit Care Med. 2007;35:2576-81.

23 Spinella PC, Perkins JG, Grathwohl KW, Repine T, Beekley AC, Sebesta J, et al. Fresh whole blood transfusions in coalition military, foreign national, and enemy combatant patients during operation Iraqi freedom at a U.S. combat support hospital. World J Surg. 2008;32:2-6.

24 Crosby WH, Howard JM. The hematologic response to wounding and to resuscitation accomplished by large transfusions of stored blood; a study of battle casualties in Korea. Blood. 1954;9:439-60.

25 Crosby WH. A study of blood transfusion as used in the treatment of battle casualties in Korea. Med Bull US. 1953;1:75-81.

26 Pinkerton PH. Norman bethune, eccentric, man of principle, man of action, surgeon, and his contribution to blood transfusion in war. Transfus Med Rev. 2007;21:255-64.

27 Pinkerton PH. Canadian surgeons and the introduction of blood transfusion in war surgery. Transfus Med Rev. 2008;22:77-86.

28 Leibner E, Andreae M, Galvagno SM, Scalea T. Damage control resuscitation. Clin Exp Emerg Med. 2020;7:5-13.

29 Holcomb JB, Jenkins D, Rhee P, Johannigman J, Mahoney P, Mehta S, et al. Damage control resuscitation: directly addressing the early coagulopathy of trauma. J Trauma. 2007;62: 307-10.

30 Van PY, Holcomb JB, Schreiber MA. Novel concepts for damage control resuscitation in trauma. Curr Opin Crit Care. 2017;23:498502.

31 Cannon JW, Khan MA, Raja AS, Cohen MJ, Como JJ, Cotton BA, et al. Damage control resuscitation in patients with severe traumatic hemorrhage: a practice management guideline from the eastern association for the surgery of trauma. J Trauma Acute Care Surg. 2017;82:605-17.

32 Cap AP, Pidcoke HF, Spinella P, Strandenes G, Borgman MA, Schreiber M, et al. Damage control resuscitation. Mil Med. 2018;183:36-43.
33 Yazer MH, Spinella PC, Anto V, Dunbar NM. Survey of group a plasma and low-titer group o whole blood use in trauma resuscitation at adult civilian level 1 trauma centers in the us. Transfusion. 2021;61(6):1757-63.

34 Yazer MH, Spinella PC. The use of low-titer group o whole blood for the resuscitation of civilian trauma patients in 2018 . Transfusion. 2018;58:2744-6.

35 Yazer MH, Spinella PC. Review of low titre group $\mathrm{O}$ whole blood use for massively bleeding patients around the world in 2019. Voxs. 2019;14(3):276-81.

36 Yazer MH, Spinella PC. An international survey on the use of low titer group o whole blood for the resuscitation of civilian trauma patients in 2020. Transfusion. 2020;60(Suppl 3): S176-9.

37 Nadler R, Tsur AM, Yazer MH, Shinar E, Moshe T, Benov A, et al. Early experience with transfusing low titer group $\mathrm{O}$ whole blood in the pre-hospital setting in Israel. Transfusion. 2020;60(Suppl 3):S10-6.

38 Bjerkvig C, Sivertsen J, Braathen H, Lunde THF, Strandenes G, Assmus J, et al. Coldstored whole blood in a Norwegian emergency helicopter service: an observational study on storage conditions and product quality. Transfusion. 2020;60:1544-51.

39 Seheult JN, Bahr MP, Spinella PC, Triulzi DJ, Yazer MH. The Dead Sea needs salt water. Massively bleeding patients need whole blood: the evolution of blood product resuscitation. Transfus Clin Biol. 2019;26:174-9.

40 Yazer MH, Cap AP, Spinella PC, Alarcon L, Triulzi DJ. How do I implement a whole blood program for massively bleeding patients? Transfusion. 2018;58:622-8.

41 Yazer MH, Cap AP, Spinella PC. Raising the standards on whole blood. J Trauma Acute Care Surg. 2018;84:S14-7.

42 Dishong D, Cap AP, Holcomb JB, Triulzi DJ, Yazer MH. The rebirth of the cool: a narrative review of the clinical outcomes of cold stored low titer group $\mathrm{O}$ whole blood recipients compared to conventional component recipients in trauma. Hematology. 2021;26(1):60111.

43 Yazer MH, Freeman A, Harrold IM, Anto V, Neal MD, Triulzi DJ, et al. Injured recipients of low titer group o whole blood have similar clinical outcomes compared to recipients of conventional component therapy: a singlecenter, retrospective study. Transfusion. 2021;61:1710-20

44 Leeper CM, Yazer MH, Morgan KM, Triulzi DJ, Gaines BA. Adverse events after low titer group o whole blood versus component product transfusion in pediatric trauma patients: a propensity-matched cohort study. Transfusion. 2021;61(9):2621-8.

45 Cotton BA, Podbielski J, Camp E, Welch T, del Junco D, Bai Y, et al. A randomized controlled pilot trial of modified whole blood versus component therapy in severely injured patients requiring large volume transfusions. Ann Surg. 2013;258:527-3.

46 Gallaher JR, Dixon A, Cockcroft A, Grey M, Dewey E, Goodman A, et al. Large volume transfusion with whole blood is safe compared with component therapy. J Trauma Acute Care Surg. 2020;89:238-45 
47 Williams J, Merutka N, Meyer D, Bai Y, Prater S, Cabrera R, et al. Safety profile and impact of low-titer group o whole blood for emergency use in trauma. J Trauma Acute Care Surg. 2020;88:87-93.

48 Duchesne J, Smith A, Lawicki S, Hunt J, Houghton A, Taghavi S, et al. Single institution trial comparing whole blood vs balanced component therapy: 50 years later. J Am Coll Surg. 2021;232(4):433-42.

49 Anand T, Obaid O, Nelson A, Chehab M, Ditillo M, Hammad A, et al. Whole blood hemostatic resuscitation in pediatric trauma: a nationwide propensity-matched analysis. J Trauma Acute Care Surg. 2021;91(4):573-8.

50 Leeper CM, Yazer MH, Triulzi DJ, Neal MD, Gaines BA. Whole blood is superior to component transfusion for injured children: a propensity matched analysis. Ann Surg. 2020; 272:590-4.

51 Shea SM, Staudt AM, Thomas KA, Schuerer D, Mielke JE, Folkerts DE, et al. The use of low-titer group $\mathrm{O}$ whole blood is independently associated with improved survival compared to component therapy in adults with severe traumatic hemorrhage. Transfusion. 2020;60 Suppl 3:S2-9.

52 Hanna K, Bible L, Chehab M, Asmar S, Douglas M, Ditillo M, et al. Nationwide analysis of whole blood hemostatic resuscitation in civilian trauma. J Trauma Acute Care Surg. 2020; 89:329-35.

53 Hazelton JP, Cannon JW, Zatorski C, Roman JS, Moore SA, Young AJ, et al. Cold-stored whole blood: a better method of trauma resuscitation? J Trauma Acute Care Surg. 2019;87: 1035-41.

54 Standards for blood banks and transfusion services. 32nded. Bethesda,AABB, 2020.

55 Yazer M, Triulzi D, Sperry J, Corcos A, Seheult J. Rate of RhD-alloimmunization after the transfusion of $\mathrm{RhD}$-positive red blood cell containing products among injured patients of childbearing age: single center experience and narrative literature review. Hematology. 2021;26(1):321-7.
56 Yazer MH, Spinella PC, Seheult JN. Low risk of future hemolytic disease of the fetus and newborn following the transfusion of $\mathrm{Rh}(\mathrm{D})$ positive blood products to $\mathrm{Rh}(\mathrm{D})$-negative children. Vox Sang. 2021. doi: 10.1111/ vox.13169.

57 Yazer MH, Delaney M, Doughty H, Dunbar NM, Al-Riyami AZ, Triulzi DJ, et al. It is time to reconsider the risks of transfusing $\mathrm{RhD}$ negative females of childbearing potential with $\mathrm{RhD}$ positive red blood cells in bleeding emergencies. Transfusion. 2019;59:3794-9.

58 Seheult JN, Stram MN, Pearce T, Bub CB, Emery SP, Kutner J, et al. The risk to future pregnancies of transfusing $\mathrm{Rh}(\mathrm{D})$-negative females of childbearing potential with $\mathrm{Rh}(\mathrm{D})$ positive red blood cells during trauma resuscitation is dependent on their age at transfusion. Vox Sang. 2021;116(7):831-40.

59 McGinity AC, Zhu CS, Greebon L, Xenakis E, Waltman E, Epley E, et al. Prehospital low-titer cold-stored whole blood: philosophy for ubiquitous utilization of O-positive product for emergency use in hemorrhage due to injury. J Trauma Acute Care Surg. 2018;84:S115-9.

60 Zwiers C, Oepkes D, Lopriore E, Klumper FJ, de Haas M, van Kamp IL. The near disappearance of fetal hydrops in relation to current state-of-the-art management of red cell alloimmunization. Prenat Diagn. 2018;38:943-50.

61 Seheult JN, Bahr M, Anto V, Alarcon LH, Corcos A, Sperry JL, et al. Safety profile of uncrossmatched, cold-stored, low-titer, group $\mathrm{O}+$ whole blood in civilian trauma patients. Transfusion. 2018;58:2280-8.

62 Seheult JN, Triulzi DJ, Alarcon LH, Sperry JL, Murdock A, Yazer MH. Measurement of haemolysis markers following transfusion of uncrossmatched, low-titre, group $\mathrm{O}+$ whole blood in civilian trauma patients: Initial experience at a level 1 trauma centre. Transfus Med. 2017;27:30-5.

63 Harrold IM, Seheult JN, Alarcon LH, Corcos A, Sperry JL, Triulzi DJ, et al. Hemolytic markers following the transfusion of uncrossmatched, cold-stored, low-titer, group $\mathrm{O}+$ whole blood in civilian trauma patients. Transfusion. 2020;60(Suppl 3):S24-30.

64 Morgan K, Yazer MH, Triulzi DJ, Strotmeyer S, Gaines B, Leeper C. Safety profile of low titer group o whole blood in pediatric patients with massive hemorrhage. Transfusion. 2021; 61 Suppl 1:S8-14.

65 Refaai MA, Fialkow LB, Heal JM, Henrichs KF, Spinelli SL, Phipps RP, et al. An association of ABO non-identical platelet and cryoprecipitate transfusions with altered red cell transfusion needs in surgical patients. Vox Sang. 2011;101:55-60.

66 Sahai T, Henrichs K, Refaai M, Heal JM, Kirkley SA, Schmidt AE, et al. ABO identical and washed blood transfusions as candidate strategies to reduce early mortality in acute promyelocytic leukemia. Leuk Res. 2017;62:1-3.

67 Refaai MA, Carter J, Henrichs KF, Davidson DC, Pollock SJ, Casey AE, et al. Alterations of platelet function and clot formation kinetics after in vitro exposure to anti-A and -B. Transfusion. 2013;53:382-93.

68 Blumberg N, Refaai M, Heal J. ABO matching of platelet transfusions - "start making sense". "As we get older, and stop making sense." the talking heads (1984). Blood Transfus. 2015;13:347-50.

69 Refaai MA, Cahill C, Masel D, Schmidt AE, Heal JM, Kirkley SA, et al. Is it time to reconsider the concepts of "universal donor" and "ABO compatible" transfusions? Anesth Analg. 2018;126:2135-8.

70 Blumberg N, Heal JM, Masel D, Refaai MA. The precautionary principle and use of group a plasma in recipients of unknown $\mathrm{ABO}$ blood group. Transfusion. 2018;58:829-31.

71 Seheult JN, Dunbar NM, Hess JR, Tuott EE, Bahmanyar M, Campbell J, et al. Transfusion of blood components containing abo-incompatible plasma does not lead to higher mortality in civilian trauma patients. Transfusion. 2020;60:2517-28.

72 Dunbar NM, Yazer MH; Safety of the use of group A plasma in trauma: the STAT study. Transfusion. 2017;57:1879-84. 